\title{
Surveillance and Entanglement: How mandatory sex offender registration impacts criminalised survivors of human trafficking
}

\author{
Kate Mogulescu and Leigh Goodmark
}

Please cite this article as: K Mogulescu and L Goodmark, 'Surveillance and Entanglement: How mandatory sex offender registration impacts criminalised survivors of human trafficking', Anti-Trafficking Review, issue 14, 2020, pp. 125130, https://doi.org/10.14197/atr.2012201410

In June 2019, Pennsylvania State Police warned of a scam targeting people convicted of sex offences. ${ }^{1}$ Masquerading as law enforcement officers, scammers were calling affected individuals and telling them that they were not complying with sex offender registry requirements, sometimes claiming that warrants existed for the person's arrest, and suggesting the problem could be eliminated by buying a cash card or transferring money to the scammer. How were the scammers getting the information needed to target these individuals? Online sex offender registry databases provide sufficient information to enable scammers to identify and find individuals to defraud. A central feature of required sex offender registration and reporting has been a publicly available notice to the community of the presence of individuals on the registry. ${ }^{2}$

1 M Gamiz, 'State police warn of new phone scam targeting sex offenders', The Morning Call, 10 June 2019, https://www.mcall.com/news/police/mc-nws-sexoffender-scam-state-police-warn-20190610-gpiqm4qihbahbi3dyt5vy6dywa-story. html.

2 See, for example: E J Letourneau et al., Evaluating the Effectiveness of Sex Offender Registration and Notification Policies for Reducing Sexual Violence against Women, Medical University of South Carolina, 2010: 'Registration is the practice of requiring convicted sex offenders to register with law enforcement and periodically update information about their residence, employment, and other details. The original aim of registration laws was to provide law enforcement with a database of information to help monitor known sex offenders and to aid in the investigation of new allegations. Community notification is the practice of releasing some registration information to citizens... All fifty states now operate publicly accessible registry websites that communicate information about registered sex offenders to citizens.' (p. 5).

This is an open-access article distributed under the terms of the Creative Commons Attribution License (CC-BY). Under the CC-BY license, the public is free to share, adapt, and make commercial use of the work. Users must always give proper attribution to the authors and the Anti-Trafficking Review. 
While this example makes plain one of the troubling consequences of publicly available registry information, the ways in which technology impacts people convicted of sex offences run far deeper. People on registries are subject to levels of ongoing surveillance that often fail to meet stated public safety or deterrence goals and raise significant due process and privacy concerns. For example, individuals convicted of sex offences in New York State, once paroled from prison, face an inordinate series of regulations governing their existence. In addition to restrictions on where they can live, work, and socialise, registered individuals are prohibited from possessing a cell phone without the express prior approval of a parole officer. The regulations make clear that, even if given permission, under no circumstance will an individual under supervision be allowed a cell phone with a camera or video capability. ${ }^{3}$ The special conditions prohibit possessing an answering machine, cross dressing (although that remains undefined), having pets, and hitchhiking. The conditions also mandate that before engaging in intimate sexual acts with anyone, a person subject to registration must provide their parole officer with the name and contact information of that person for approval and must disclose to the person with whom they intend to be intimate the nature of their offence of conviction in front of their parole officer.

At first glance, it might be difficult to see why the potential scam in Pennsylvania, the availability of sex offender registration information online, or the numerous and onerous conditions placed on individuals convicted of sex offences would be relevant to victims of human trafficking. But the pool of those required to register as sex offenders includes a significant number of people who have been trafficked and who have been convicted of crimes related to their own trafficking situations.

Over the last several years, the pressure to increase investigation and prosecution of trafficking has been intense; it is one of the few issues in American politics with bipartisan support. In 2018, the United States Department of Justice made USD 77 million in discretionary grants available to combat trafficking, much of which went to law enforcement. ${ }^{4}$ Advocacy groups, decrying law enforcement's failure to take trafficking seriously, have developed reports, protocols, and guidance for police and prosecutors designed to facilitate their investigation and prosecution of sex trafficking cases. ${ }^{5}$

3 New York State Department of Corrections \& Community Supervision, Special Conditions of Release to Community Supervision for Sex Offenders, on file with authors.

4 See Matrix of OVC/BJA-Funded Human Trafficking Services Grantees and Task Forces, https://ovc.ncjrs.gov/humantrafficking/traffickingmatrix.html.

5 While we agree that the term 'sex trafficking' is problematic (see B Chapman-Schmidt, "'Sex Trafficking” as Epistemic Violence', Anti-Trafficking Review, issue 12, 2019, https://doi.org/10.14197/atr.2012191211), we have used this language here because that is the name of the crime with which victims of trafficking are being charged. 
This zealous prosecution of human trafficking has had serious unintended consequences for a subset of victims, who are often prosecuted alongside their traffickers. They are found guilty of violations of federal and state trafficking laws despite their own victimisation. Frequently, victims facing prosecution plead guilty rather than defend against the charges in order to avoid draconian sentences. Yet, because the sentencing ranges on these offences begin so high, victims still end up with lengthy sentences that include years of imprisonment. For example, many trafficking charges carry a statutory minimum of 25 years to life. With the threat of these sentences hanging over their heads, individuals facing charges agree to plea bargains and sentences in the 10-15-year range. Perversely, prosecutors consider these sentences favourable outcomes.

These cases arise in a number of ways. Sometimes the women are minimally involved in a trafficking operation. Some are acting under orders from their own traffickers, who may be trying to distance themselves from illegal activity. Some are trying to protect other victims by minimising their interactions with or punishment from traffickers. Some have been abused in intimate relationships with their traffickers, who use violence and control to keep them entrapped and compel them to engage in illegal activity. The contexts for these victims' actions are rarely explored during prosecution and have a minimal, if any, impact on sentencing. And at sentencing, victims often learn that not only will they face long periods of incarceration, but that federal judges must order them to register as sex offenders when they are released. Being found guilty of human trafficking at the federal level, and in most US states, comes with mandatory registration as a sex offender.

That sex offender registries have been used to further marginalise vulnerable individuals and control sexual behaviour deemed undesirable or deviant is not new. ${ }^{6}$ But the more recent emphasis on the policing of commercial sex to combat human trafficking has brought with it an increased number of people subject to the monitoring and punishment of the registration system. Not surprisingly, this group overwhelmingly includes women in the commercial sex industry, many of whom have themselves faced exploitation and coercion but are charged as the ultimate bad actors.

When considering the registration scheme, and the technological surveillance it entails, with respect to this group of women, the hypocritical nature of the policing that lead to their registration becomes clear. In the United States, the discourse around human trafficking focuses on trafficking for the purposes of sexual exploitation and pays lip-service to supporting victims and being victim-centred.

6 See, for example: E Meiners, 'Awful Acts and the Trouble with Normal', in E Stanley and N Smith (eds.), Captive Genders: Trans embodiment and the prison industrial complex, Second Edition, AK Press, Oakland, 2015. 
Yet a careful look at who is prosecuted for sex trafficking and other sex offences exposes the ways in which rhetoric and reality fail to align. When mandated sex offender registration is added to the already suffocating burdens of criminalisation, the harm done to victims of trafficking makes moving forward nearly impossible.

The Human Trafficking Clemency Initiative (HTCI), a consortium of law school clinical programmes and legal services providers, represents clients all over the country who are seeking clemency after being convicted of federal crimes related to their own trafficking. One HTCI client was prosecuted as a trafficker after being forced to drive women who she did not know were underage to places where they engaged in prostitution. Another was convicted of sex trafficking and sentenced to fourteen years in prison a few months after her eighteenth birthday because she engaged in prostitution alongside two younger teenagers. HTCI clients all face lengthy terms of registration as sex offenders as a result of their convictions for such crimes. And because technology makes it possible for anyone to access an online sex offender registry, these clients are vulnerable to further abuse and exploitation as a result of the registration requirement.

Additionally, survivors of trafficking who have been prosecuted as traffickers must navigate complicated technological surveillance and limitations that exacerbate the burden of their punishment. ${ }^{7}$ When survivors return to their communities from prison, but are not allowed to own a cell phone, they are unable to secure employment, housing or communicate with family.

In almost every instance, people on parole convicted of a sex offence have to waive any privacy rights to electronic communications, social media, or even simple word processing documents on their computers. Accordingly, law enforcement can search contacts and communications without a warrant or judicial subpoena. For survivors of trafficking who have been convicted of sex offences, this compromised privacy means living under the spectre of involuntary involvement in investigations. Taken as a whole, the message to survivors who are made to comply with sex offender registration requirements is clear-you are a criminal, you have no privacy, and you cannot utilise technology in the way that this modern world demands.

For the survivor prosecuted in New York State in her early 20s for sex trafficking because she was engaging in prostitution alongside minors, release from state prison came with all the restrictions described above. Coupled with the stigma of having to register, and the barriers that brings, she struggled to find employment.

\footnotetext{
L Adkins, 'Labels, Supervision, and Surveillance: Motherhood and sex offender status', The Scholar \& Feminist Online, issue 15.3, 2019, http://sfonline.barnard.edu/ unraveling-criminalizing-webs-building-police-free-futures/labels-supervisionsurveillance-motherhood-sex-offender-status.
} 
Her first parole violation, approximately 30 days after her release, was for possessing a cell phone, accessing the Internet, and engaging in sex work. In any other instance, mere possession of a phone or using social media would not be deemed criminal. In any other instance, her alleged continued sex work would likely not have come to the attention of law enforcement and, even if it had, at most she would have faced prosecution for a low-level misdemeanour that carried no actual risk of jail time. But as someone who had been convicted of a sex offence, she was subject to surveillance and reporting that kept her entangled in the legal system. This surveillance failed to take into account the acute struggle for survival that accompanied her re-entry into society. After her parole violation, the state returned her to prison and incarcerated her for an additional six months. After serving that sentence, she was released to parole again with another cycle of barriers, monitoring and control.

In other cases, the pressure on law enforcement and prosecuting agencies to investigate human trafficking leads to harmful and unsafe situations for survivors who are made to register as sex offenders. The personal information of survivors on the registry is available to the public, and their communications, documents and belongings are not private. Parole officers can demand access to any information without probable cause. The consistent risk of forced disclosure means that survivors can be made to participate in law enforcement investigations against their will. Their information can be used in ways that place them in danger. Witnesses and victims have rights in criminal investigations; survivors marked as sex offenders do not.

The whole system of sex offender registries deserves a careful, critical look. For survivors of human trafficking in particular, criminalisation and being designated a sex offender cause specific and distinct harm. One way to counteract this troubling trend is to allow sentencing courts the ability to decline to impose sex offender registration requirements in appropriate circumstances. Pending legislation in Kansas would be the first of its kind to allow judges to do precisely that. ${ }^{8}$ People currently on registries must have a way to demonstrate that registration is unjust and unnecessary. As it stands, there are few if any mechanisms that allow survivors to do so. At the very least, courts should be able to consider prior victimisation as a mitigating factor when sentencing trafficking survivors and use that evidence to justify imposing the least intrusive possible sentences. Finally, as is often the case, we must interrogate our policing and prosecution strategies that support outcomes that are harmful to trafficking survivors and other vulnerable populations. Pursuing survivors as human traffickers has been an easy way for the government to inflate statistics on trafficking prosecutions. As in so many other contexts, the true solution to preventing the harms of over-

8 Kansas Senate Bill 227, introduced 14 March 2019, available at http://www. kslegislature.org/li/b2019_20/measures/sb227. 
criminalisation, including those harms made possible by technology, may simply be fewer arrests and prosecutions.

Criminal punishment is often presented as a binary - a person 'does their time', then returns to society punishment-free. The literature on collateral consequences makes it clear that this notion of punishment as a binary is misguided. But few collateral consequences pose as significant a burden to those convicted of crimes as the requirement that they register as sex offenders. Required registration, sometimes for an entire lifetime, precludes trafficking victims convicted of crimes resulting from their own victimisation from ever being free of punishment. When trafficking survivors' registration information is publicly available, technology makes their ongoing punishment exponentially harsher and renders their existence significantly more dangerous.

Kate Mogulescu is an Assistant Professor of Clinical Law at Brooklyn Law School, where she directs the Criminal Defense \& Advocacy Clinic. Her work and scholarship concentrate on gender issues in the criminal legal system, with a focus on sex work and human trafficking. Kate has founded several projects that attempt to address the criminalisation of vulnerable and exploited people, including the Exploitation Intervention Project (2011), the Survivor Reentry Project (2016) and the Human Trafficking Clemency Initiative (2017). Professor Mogulescu received her J.D. from Yale Law School and B.A. from the State University of New York at Binghamton. Email: kate.mogulescu@brooklaw.edu

Leigh Goodmark is the Marjorie Cook Professor of Law and Co-Director of the Clinical Law Program at the University of Maryland Carey School of Law, where she directs the Gender Violence Clinic. Professor Goodmark's scholarship focuses on intimate partner violence. She is the author of Decriminalizing Domestic Violence: A balanced policy approach to intimate partner violence (UC Press, 2018) and $A$ Troubled Marriage: Domestic violence and the legal system (New York University Press, 2012) and the co-editor of Comparative Perspectives on Gender Violence: Lessons from efforts worldwide (Oxford University Press, 2015). Professor Goodmark is a graduate of Yale University and Stanford Law School. Email: lgoodmark@law.umaryland.edu 